\title{
Technology, Structural Change and BOP Constrained Growth: A Structuralist Toolbox
}

\author{
Mario Cimoli* and Gabriel Porcile** \\ (*) ECLAC and University of Venice \\ (**) ECLAC and UFPR \\ August 2011
}

\begin{abstract}
The Latin American Structuralism (LAS) is a significant part of the heterodox tradition in the theory of long run growth, with a focus on the problems of developing economies which started their industrialization process when other regions had already accumulated substantial technological capabilities. The emergence of a centre-periphery system posed specific problems to growth and distribution in laggard economies which LAS discusses in a systematic way. In this paper we presented a simple model which, firstly, captures key insights of the LAS school, such as the persistency of technological asymmetries and structural heterogeneity; secondly, it can be used to analyze the impacts of shocks and policies based on how they affect supply-side and demand side parameters of the model; thirdly, it links more closely (Post-) Keynesian macroeconomics based on the BOP constraint with the evolutionary microeconomics concerned with the dynamics of learning; lastly, it can be used as a toolbox and a teachable model in the analysis of the interactions between structural change, technological catching up and long run growth.
\end{abstract}




\section{Introduction}

This paper presents a simple model which is intended to convey many of the key insights of the Latin American Structuralism (LAS) in development theory. The model can be seen as a structuralist toolbox that allows for discussing policies and shocks, and it is also simple enough to be used as a teachable model. We will first define what we understand by LAS and then point out why we believe that a LAS toolbox may be useful for both students and researchers of economic development.

What is the LAS tradition? As happens with other schools of thought, there is no consensual definition of what LAS exactly means. We will pick up here some distinctive features of this school which, however, are not exhaustive ${ }^{1}$. We define LAS ideas as based on the perception that the international system is formed by two poles, the North (centre) and the South (periphery), whose economies are structurally different: while the North is diversified and shows levels of labor productivity relatively homogeneous across sectors, the South specializes in a narrow set of commodities with large differences in labor productivity, within and between sectors. The existence of such differences in productivity and the fact that a significant part of the labor force in the South is allocated in the subsistence sector and/or in the informal labor market is called structural heterogeneity ${ }^{2}$.

Why may a LAS toolbox be of interest? Three are the motivations of the paper.

First, the dominance of mainstream economics in most economic departments has meant that LAS is not very well known by most students of economic development and (we dare to say) by a significant part of the economic profession of neoclassical persuasion. We expect that our toolbox could be helpful to bring LAS ideas to a broader audience of students and researchers interested in the theory and policy of economic development. Secondly, we aim to integrate LAS more closely with other heterodox strains of thought in growth theory, particularly with the Post-Keynesian and Schumpeterian schools. It is worth recalling that the LAS approach shares with these schools the demand-side view of growth based on the BOP-constraint (Rodríguez, 1977). The "closure equation" of LAS models is precisely Thirlwall's Law (Thirlwall, 1979). Hence LAS should be seen as part of a broader current of heterodox thinking, to which it makes specific (and we believe valuable) contributions ${ }^{3}$. Lastly, the toolbox can be applied to the analysis of the effects on developing economies of different shocks -- like shocks in international demand and terms of trade - and policies - like industrial, technological and trade policies. We offer in the paper several examples of how these shocks can be treated within the simple set of equations and graphs derived from.

The paper is organized in three sections plus the introduction and the concluding remarks. Section 1 presents the model, while section 2 uses a set of four graphs to discuss the impact of shocks and policies on growth, heterogeneity and structural

\footnotetext{
1 Classical pioneer contributions are Prebisch (1949) and ECLAC (1955). Rodriguez (2007) and Bielshowski (2009) revisit and discuss the different phases in the evolution of LAS ideas.

${ }^{2}$ Differences in labor productivity within and between sectors are of course an inherent feature of technological learning and competition in all types of economies (Dosi et al, 2010). What is specific to the developing economies in general and to Latin America in particular is the large magnitude of these differences. See Pinto (1976) and Infante and Sunkel (2009).

3 Botta (2009) explores some of the complementarities between the Latin American tradition and heterodox growth models. See also Rada (2007) and Ciarli et al (2010).
} 
change. We keep the formal analysis in sections 1 and 2 as simple as possible, reserving for section 3 a more rigorous discussion of the dynamic properties of the model.

\section{The Long Run LAS Model}

\subsection{The technology gap}

As mentioned, at the origin of LAS is the idea that the international diffusion of technology is slow and irregular (Prebisch, 1949). The North takes the lead in innovation while the South lags behind. Since technical change is closely associated with structural change and the emergence of new sectors, goods and skills, the productive structure of the center diversifies, going through major transformations. But these transformations and technological change solely reach localized tracts of the Southern productive structure. As a result, the South remains highly specialized in few (less technology-intensive) sectors and keeps a large share of its workers in lowproductivity and subsistence activities. The two structures - diversified and homogeneous (centre/North) versus specialized and heterogeneous (periphery/South) emerge out of the asymmetric dynamics captured by the concept of the technology gap.

We therefore begin with the dynamics of the technology gap, defined as $G=T n / T s$, in which $T n$ represents technological capabilities in the North and $T s$ technological capabilities in the South. This dynamics is driven by two variables -- the technology gap itself and increasing returns to relative South/North growth $y \equiv\left(y_{s} / y_{n}\right)$ arising from the Kaldor-Verdoorn Law -- as suggested in the following differential equation:

$$
\text { (1) } \dot{G}=u-v G-g y
$$

All parameters $(u, v, g)$ are positive and $G$ is constrained to be higher than the unity (i.e., the North is on the technological frontier while the South is a technological laggard), while $y$ is constrained to be positive. This equation states, firstly, that the growth of the gap falls when the gap increases. This happens because the higher the technology gap, the higher the opportunities for learning related to imitation, international technological spillovers and catching up in the South. In other words, the technology gap offers the possibility of using existing foreign technology to build up indigenous capabilities ${ }^{4}$. Secondly, a higher relative South-North rate of growth enhances the various mechanisms of learning by doing in the South and therefore slows down the rate of growth of the technology gap 5 .

In equilibrium, the technology gap will be stable and hence $\dot{G}=0$. Using (1), this implies that in equilibrium the gap will be given by:

$$
\text { (2) } G=\frac{u-g y}{v}
$$

\footnotetext{
${ }^{4}$ This may not be always the case and later we will discuss what happens to international technological asymmetries when $v<0$. The relationship between the level of the gap and its dynamics is addressed by Verspagen (1993), who uses a nonlinear specification in order to capture the cases in which the gap is so high that imitation of technology is no longer possible. See also Narula (2004).

${ }^{5}$ The Kaldor-Verdoorn Law is an important part of heterodox growth models, see León-Ledesma (2002), Rada (2007), Porcile and Lima (2010) and Pérez (2011).
} 
Equation (2) gives all the combinations of $G$ and $y$ that keep stable the technology gap. If technological learning increases in the South out of an increase in relative growth, then the technology gap has to fall so as to reduce international spillovers of technology keeping $\dot{G}=0$. We will work hereafter with the equilibrium technology gap stated in (2) and leave for section 3 the analysis of the dynamics of the model, in particular how the gap interacts with growth and structural change.

\section{2. $\quad$ Relative productivity and relative wages}

To discuss structural change we need a multi-sector model. This is of course not a new concern in heterodox growth theory, and several contributions already exist that have sought to analyze BOP-constrained growth within a multi-sector framework (Araujo and Lima, 2007). We will draw from the strain of models based on the Ricardian approach initially proposed by Dornbusch et al (1977) and subsequently developed by Cimoli (1988) and Dosi et al (1990), among others. In the Ricardian model there are two factors of production, homogeneous labor and technology. We will modify the model to include the specific features stressed by LAS (see above), namely the technology gap and the links that exist between specialization and the BOP constraint.

A good $i$ will be produced in the South if unitary costs of production are lower than in the North. Formally:

$$
\left(W_{s} / \pi_{s}^{i}\right) \leq\left(W_{n} e / \pi_{n}^{i}\right)
$$

where $W_{s}$ are nominal wages in the South, $W_{n}$ are nominal wages in the North (in units of the North currency), $e$ is the nominal exchange rate (units of South currency per unit of North currency), $\pi_{s}^{i}$ is labor productivity in the production of $i$ in the South and $\pi_{n}^{i}$ labor productivity in the production of $i$ in the North. Both $\pi$ and $W$ are constrained to adopt positive values. It is straightforward that this condition is equivalent to the following:

$$
\frac{\pi_{s}^{i}}{\pi_{n}^{i}} \equiv \pi^{i} \geq W \equiv \frac{W_{s}}{W_{n} e}
$$

In other words: if relative productivity (defined as $\pi \equiv \pi_{s} / \pi_{n}$ ) is higher than relative wages ( $W \equiv W_{s} / W_{n} e$ ), then the good will be produced in the South.

What are the determinants of South-North relative labor productivity? The first determinant is the technology gap: differences in labor productivity depend on differences in technological capabilities. Therefore, the higher the technological NorthSouth gap, the lower the relative productivity of the South respecting that of the North for all goods. The second variable shaping the $\pi$-function is the technological intensity of the good. Goods are not all the same in terms of the technological complexity of the production process. The higher is the technological intensity of the good, the higher will be the North-South productivity gap for a given technology gap. North and South are 
distinguished on the basis of their asymmetric technological capabilities. Such asymmetries manifests more strongly in high tech goods ${ }^{6}$.

It is then possible to order all the goods produced in the South in a ranking beginning with the good with the highest relative labor productivity in the South $(N=1$, the good with the least technological intensity) to the good with the lowest relative labor productivity ( $N=N_{\mathrm{S}}$, the good with the highest technological intensity). Therefore, by construction we get a negatively slopped $\pi(N)$ curve that shows how relative labor productivity falls as the technological intensity of the goods increases from $N=1$ to $N=N_{\mathrm{S}}$ :

$$
\text { (4) } \pi=a-b N-k G
$$

All parameters ( $a, b$ and $k$ ) are positive and $N$ is constrained to be positive. Finally, relative wages are a function of the relative South-North rate of growth:

$$
\text { (5) } W=W(y), W_{y} \geq 0
$$

At least two forces concur to explain why relative wages respond to growth. Firstly, higher rates of relative growth imply higher rates of labor demand tilting the bargaining process in favor of labor. Secondly, relative growth raises labor relative productivity, which in turn boosts wages in the South. Still, in a developing economy in which large part of the labor force is allocated in the subsistence sector it should be expected a very slow reaction of wages to growth ${ }^{7}$. It is even possible for the slope of the $W(y)$ curve to be zero for a large set of values of relative growth and become positive solely after a critical value $y^{*}$ is reached.

\subsection{Specialization and growth}

For equation (4) we know that the $\pi(N)$ curve is negatively sloped and for equation (3) we know that the "last" good $N^{*}$ for which the South will be competitive in the international economy satisfies the following equality:

$$
\text { (6) } \pi(N *)=W *
$$

For all $N>N^{*}$ then $\pi<W$, unitary costs will be higher in the South and these goods will be produced solely in the North. Hence, the pattern of specialization of the South is defined by the number $N^{*}$ of goods that satisfies (6). Under the assumption that the ranking of goods in accordance with a declining North-South relative productivity is also a ranking in terms of increasing technological intensity, then $N^{*}$ is the index of technological intensity of the Southern productive structure in an open economy.

\footnotetext{
${ }^{6}$ Labor productivity does not only depend on technology but also on the availability of natural resources and capital. Still, to keep the model simple and emphasize the role played by technology in international competitiveness, we have assumed just two factors of production - homogeneous labor and technology.

${ }^{7}$ A discussion of the forces governing wages in an economy with a large labor surplus can be found in Ros (2000). The classical reference is Lewis (1956).
} 
The relative rate of growth $\left(\frac{y_{s}}{y_{n}} \equiv y\right)$ is the BOP-constrained rate of growth set forth in Thirlwall's Law ${ }^{8}$ :

$$
\text { (7) } y=\frac{\varepsilon_{X}}{\varepsilon_{M}} \equiv \varepsilon
$$

In equation (7) $\varepsilon_{X}$ is the income elasticity of the demand for exports and $\varepsilon_{M}$ is the income elasticity of the demand for imports of the South, while $\varepsilon$ is the income elasticity ratio. For this equation to be valid we take on board a set of assumptions, in particular that autonomous expenditure (private and public) always expand or contract so as to avoid the accumulation of reserves or an explosive external debt, respectively ${ }^{9}$. In other words, changes in autonomous expenditure always allow the economy to adjust to the BOP-constrained rate of growth.

The income elasticity ratio is a function of the productive structure of the South. We have described this structure by the number $N^{*}$, an index of technological complexity which also represents the number of goods in which the South is competitive. The empirical evidence suggests that high-tech goods are more likely to display a higher income elasticity of demand (Dosi et al, 1990; ECLAC, 2007; Gouvea and Lima, 2010; Cimoli et al, 2010). Therefore, the higher $N$, the higher is the income elasticity ratio $\varepsilon$. Of course, exceptions to this rule exist, such as the good luck of a country in the "commodity lottery". Countries which have natural resources in high demand in the international economy will grow faster (at least during some time) in spite of lagging behind in technological capabilities. Yet when we look at the long run economic history is fairly conclusive in suggesting that there is a clear association between technological capabilities, patterns of specialization and economic growth (Reinert, 1995).

Formally, we may rewrite equation (7) as:

$$
\text { (8) } y=\varepsilon(N), \varepsilon_{N}>0
$$

In sum, relative productivity and relative wages define the pattern of specialization of the South, represented by an index of technological complexity of the Southern productive structure. Such an index has a positive association with the income elasticity ratio and hence with the BOP-constrained rate of economic growth.

\footnotetext{
${ }^{8}$ For a discussion of the BOP-constrained growth model and a comparison with Kaldorian models see Blecker (2011). See also Dutt (2002). A recent reappraisal can be found in Thirlwall (2011).

${ }^{9}$ This implies that the government will always be ready to either expand or contract total expenditure so as to keep the effective rate of growth in line with the BOP-constrained rate of growth. Capital inflows may move the effective rate of growth away of the equilibrium rate of growth given by the simplest version of Thirlwall's Law. Still, McCombie and Thirlwall (1997) and Thirlwall (2011, p. 28) show that even large inflows of capital have little quantitative impact on the equilibrium rate of growth with a sustainable deficit to GDP ratio. We do not consider such flows in this paper; see on this Moreno-Brid (2003) and Vera (2006).
} 


\subsection{Equilibrium and implications}

Equations (2), (4), (5), (6), (7) and (8) allows for finding the equilibrium values of six endogenous variables: the technology gap $(G)$, relative South-North productivity $(\pi)$, the income elasticity ratio $(\varepsilon)$, relative growth $(y)$ and relative wages $(W)$.

We use equation (2) in (4) to rewrite relative productivity as:

$$
\text { (9) } \pi=\beta-b N+\alpha \varepsilon(N)
$$

where $\beta \equiv a-k(u / v)$ and $\alpha \equiv k g / v$. In order to find explicit solutions for the system, we specify $\varepsilon(N)$ as a linear function of $N$ and use (8) to get:

$$
\text { (10) } y=h N
$$

where $h$ is strictly positive. We also specify $W(y)$ as a linear function of $y$ :

$$
W=j y
$$

where $j \geq 0$. Using equation (10) in (9) and (11) we obtain, respectively:

$$
\text { (12) } \pi=\beta-(b-\alpha h) N
$$

(13) $W=j h N$

In equilibrium $\pi\left(N^{*}\right)=j h N^{*}$, which allows for finding $N^{*}$ and with it the equilibrium relative rate of growth, relative wages, the technology gap and relative productivity:

$$
\begin{aligned}
& \text { (14) } N^{*}=\frac{\beta}{b+h(j-\alpha)} \\
& \text { (15) } y^{*}=\varepsilon^{*}=\frac{h \beta}{b+h(j-\alpha)} \\
& \text { (16) } W^{*}=\frac{j h \beta}{b+h(j-\alpha)} \\
& \text { (17) } G^{*}=\frac{u}{v}-\frac{g h}{v}\left[\frac{h \beta}{b+h(j-\alpha)}\right] \\
& \text { (18) } \pi^{*}=a-(b-\alpha h)\left[\frac{h \beta}{b+h(j-\alpha)}\right]
\end{aligned}
$$

For a meaningful solution (endogenous variables are constrained to be positive) its is necessary that $b+h(j-\alpha)>0$. This condition is also required for having a stable solution for the dynamic system (see section 3 ). The parameter $j$ tend to be rather low, so it can be expected that $(j-\alpha)<0$. In the extreme case in which $j=0$ and relative wages do not respond to growth, the stability condition boils down to $b>\alpha h$-- i.e. differences in labor productivity across sectors should be higher than the rise in productivity from increasing returns to diversification. 
Box 1 presents the signals of the partial derivatives of $N^{*}, \varepsilon, y^{*}, W^{*}$ and $\mathrm{G}^{*}$ respecting some of the exogenous parameters of the model.

\section{Box 1: Signals of partial derivatives}

\begin{tabular}{|c|c|c|c|c|c|}
\hline $\begin{array}{l}\text { Variable/para } \\
\text { meter }\end{array}$ & $\beta$ & $\alpha$ & $H$ & $B$ & $J$ \\
\hline$N^{*}$ & + & + & + & - & - \\
\hline$\varepsilon *$ & + & + & + & - & - \\
\hline$y^{*}$ & + & + & + & - & - \\
\hline$W^{*}$ & + & + & + & - & +- \\
\hline$G^{*}$ & - & - & - & - & + \\
\hline
\end{tabular}

From the analysis of the equilibrium solutions and the partial derivatives in Box 1 it is possible to draw some implications of the model.

Firstly, growth is demand-led in the sense that any effect of the supply side variables on growth is necessarily mediated by its specific effect upon the elasticity ratio. In the same vein, any increase in the exogenous rate of growth of the North will raise the demand for exports in the South and hence economic growth in the South, even if relative South-North growth does not change.

Secondly, pure demand-side shocks that raise $h$, like a change in international patterns of demand or export promotion policies in the South, will produce persistent higher relative growth along with higher relative wages in the South ${ }^{10}$. Moreover, a rise in $h$ reduces the technology gap $G$ as a result of the learning-enhancing effects of faster growth.

Thirdly, industrial and technological policies aimed at reducing the technology gap and fostering structural change heightens the elasticity ratio. As a result, they also increase the relative rate of growth along with relative wages in the South. Still, it is very important to note that supply side parameters are seen in this paper from an evolutionary perspective. Supply-side responses are not related to price flexibility or to the swift reallocation of factors of production, but to systems of learning and innovation based on the interaction between institutions, policies and the productive structure (Freeman, 1995). Although this point is not explored in this paper, one should keep in mind that the micro that explains North-South technological asymmetries and heterogeneity is very different from a micro based on optimization and representative agents, and so are its policy implications ${ }^{11}$.

Lastly, if $j>0$, a rise in $h$ or a in the technological parameters will always lead to both higher growth and higher relative wages. On the other hand, a rise in $j$ (due to an increase in the bargaining power of workers) may give rise to a trade-off between growth and relative wages. A rise in $j$ always reduces the degree of diversification of the Southern productive structure. But its effect on relative wages is ambiguous: if $b>$

${ }^{10}$ See Setterfield (2009) for a discussion of the role of the supply and demand sides in shaping long run growth in both orthodox and heterodox growth models.

${ }^{11}$ Cf. Dosi (1988) and Metcalfe (2001). Please note that a competitive process in oligopolistic markets, based on technological asymmetries and leads and lags in technological capabilities, is precisely the type of micro which is consistent with the LAS tradition, in which the centre-periphery productive dynamics is by large driven by these asymmetries (see Cimoli and Porcile, 2011a and 2011b) 
$\alpha h$, relative wages increase when $j$ increases. In an economy in which increasing returns represented by the parameter $\alpha$ are low (linking economic growth and productivity growth), or in which the economy fails to translate diversification into a boost in effective demand (as represented by $h$ ), then a stronger bargaining power of unions reduces relative growth while increasing relative wages. But if $\alpha$ and $h$ are high, then a rise in $j$ leads to both lower growth and lower relative wages. As a corollary, an economy which seeks to boost competitiveness through lower relative wages should lend high priority to a parallel effort for strengthening learning and demand growth. Otherwise the result would be lower relative wages in the long run with just a modest increase in diversification.

In the following section we use the model as a toolbox for addressing the effects of different kind of exogenous shocks, either in policies or in the international economy. We produce a set of graphs (derived from the equations of the previous section) which is fairly intuitive and may be used as a teaching device of LAS analysis.

\section{Shocks and Policies}

In this section we discuss the impacts on growth and structural change of three types of shocks: 1) demand shocks (negative and positive) that affect the income elasticity ratio; 2) supply-side shocks, related to technological policies affecting the learning coefficients; 3 ) changes in the industrial and trade policies that affect both supply-side and demand-side parameters.

The analysis is based on the six-equation model presented above, summarized in four graphs ${ }^{12}$. To simplify the graphical analysis, we used equation (9) that combines equations (2) and (4); we assumed that the relative wage curve is flat for the relevant interval of changes in $y$ (i.e. $W$ is constant); and represented only changes in $N, \varepsilon$, y and $W$ (changes in $G$ are not represented, but can be easily obtained from equation 2 ). Dynamics is treated in section 3.

\subsection{A negative demand shock}

We will first discuss the impacts of a negative demand shock that reduces $h$ and hence the income elasticity ratio - either by reducing the elasticity of the demand for exports and / or by raising the income elasticity of the demand for imports - for a given productive structure $N$. Several factors may produce such an effect: a change in patterns of international demand arising from technological change, new substitutes of commodities produced in the South, and / or a shift in consumers' preferences.

Figure 1A shows how the pattern of specialization is defined by combining the curves of relative productivity and relative wages (equations 9 and 11, respectively). Figure 1B represents the income elasticity ratio as a function of the technological intensity of the productive structure $N$ (equation 8 ). The 450 line in figure $1 \mathrm{C}$ translates the income elasticity ratio into relative growth, as suggested by the BOP-constrained growth model (equation 10 and figure 1C), where causality goes from elasticities to growth. Economic growth combined with the rate of productivity growth in the South

12 Our main focus is on long run steady state positions: this implies that we will ignore short run disturbances or policies that are adopted for such a short period of time that do not have significant effects in any of the structural parameters of the model. On the other hand, the model may capture the effect of a policy which is basically aimed to stabilize the economy in the short run but which - if it lasts for a sufficient period of time - affects the structural parameters of the model. 
(more on this below) gives the rate at which labor surplus is absorbed in the South. As mentioned, we assume that the economy is in the range of relative growth in which labor supply is perfectly elastic $(j=0)$ and relative wages are constant (figure 1D).

\section{Figure 1 about here}

The impact of a negative shock in the income elasticity ratio of the South can be assessed using figures from 1A to 1D. Such a shock will lower $h$ and this implies that the curve $y=h N$ shifts to the left in figure 1B. Initially $N$ does not change and hence only the demand-led rate of relative growth varies, reflecting the fact that effective demand for peripheral goods has fallen. This is represented by the move from point $X$ to $\mathrm{Z}$ in figures 1B (relative elasticity) and 1C (relative growth). Still, the change in $h$ also produces a change in the slope of the curve of relative productivities (in figure 1A), due to a fall in the technology gap. The new curve of relative productivities gives rise to a lower $N^{*}$, as represented by the new equilibrium at point $\mathrm{Y}$. Therefore, the negative shock in demand brings on a process of regressive structural change which renders lower relative growth in equilibrium.

\subsection{A positive demand shock: staples theory and Dutch disease}

We now address the opposite shock to the one considered above: a positive shock that boosts the international demand for and the price of the goods produced by the South. A first scenario is the one defined by staple theory, in which a more favorable international environment (a rise in $h$ ) implies a stronger response of Southern exports to global growth (shift from point $X$ to $Z_{1}$ in Figure $2 B$ ). This in turn fosters relative economic growth in the South (which increases to $Z_{1}$ in Figure $2 C$ ), speeding up learning and moving to the right the $\pi$-curve. From such a virtuous process emerges a higher level of diversification of the productive structure $\left(N^{3}\right.$, in figure $\left.2 \mathrm{~A}\right)$ and higher relative growth in equilibrium. We assume that throughout this process relative wages remain constant (figure 2D). All the process so far mirrors the effects of the negative shock discussed above. In particular, an economy specialized in natural resources may be able to diversify its export structure after a positive shock in the demand for naturally resources on the basis of the virtuous effects of growth on learning.

Still, a different scenario emerges if prices experience rapid growth in the South (higher inflation than in the North, for a given nominal exchange rate) as a response to the boom, or if the nominal exchange rate falls (for the same inflation rates in North and South) out of the abundant supply of foreign exchange. In both cases the real exchange rate (RER) falls. Assuming a fall in $e$, the curve $W=W^{P} / W^{C} e$ will shift upwards in figure 2D (from $W_{1}$ to $W_{2}$ ). The appreciation of the domestic currency of the South will compromise the international competitiveness of a broad set of sectors -- precisely those in which the productivity gap is higher -- giving rise to the Dutch Disease case: a positive shock in commodity exports produces a fall in the RER which drives out of business other tradable goods. In the new equilibrium (with diversification $N_{2}$ at point $\mathrm{Z}_{2}$ instead of $N_{1}$ at $\mathrm{Z}_{1}$ ) the South displays lower relative growth and less employment in the modern sector.

\section{Figure 2 about here}

Which of the two scenarios will emerge depends on policies and technology. The Dutch Disease could be avoided if (i) the South uses the rents derived from higher 
commodity prices for changing the technological parameters of the system ( $a, b$ and $\alpha$, see below); (ii) the South uses the monetary and fiscal policies to prevent the appreciation of the exchange rate ${ }^{13}$; (iii) the South uses any combination of the two previous policies to sustain the level of productive diversification (avoid regressive structural change from $N^{l}$ to $N^{2}$ ). On the other hand, if path-dependency and hysteresis phenomena emerge from strong technological or systemic rigidities in the economy, the Dutch Disease outcome will prevail, compromising long run growth.

\section{3. $\quad$ Supply side shocks}

We will now assume that the South adopts an active technological policy that increases $a, \alpha$ and/or reduces $b$. In this case the dynamic process begins in figure 3A: the curve of relative productivity shifts to the right; this in turn changes relative elasticity (figure 3B) and relative growth (figure 3C) in the South. Although relative wages do not change in figure 3D, a growing share of the total workforce in the South will be reallocated to the modern sector, thereby reducing heterogeneity. The new equilibrium features a higher level of industrial diversification and higher relative growth (move from $N^{1}$ to $N^{2}$ and from points $\mathrm{X}$ to $\mathrm{Z}$ ).

Figure 3 about here

\subsection{Industrial and trade policies: export promotion and import $\underline{\text { substitution }}$}

As regards industrial policy -- defined as a policy that targets specific sectors of the economy -- it can adopt different forms. One of them is providing subsidies to specific industries that are more technology- (or learning-) intensive than others (industries with higher $N$ ). To the extent that this produces externalities that heighten productivity in the whole economic system, such a policy leads to an increase in $\alpha$ or a fall in $b$. The analysis is therefore similar to that of the previous case.

Other forms of industrial policies affect trade flows. For instance, subsidies to exports of goods that are deemed to be more technologically intensive will affect positively both supply side parameters (such as $\alpha$ ) and demand side parameters (such as $h$ ). It should be observed that a sufficiently strong upward shock in these two parameters ( $\alpha$ and $h$ ) may change substantially the dynamics of the North-South system (see section 3). In effect, for high values of these parameters the system will become instable and the South will be able to raise boundlessly its relative rate of growth. Such an outcome of course cannot continue forever: there will be a reversal of positions in the North-South model, becoming the former South a new North, more diversified and with higher technological capabilities than the countries that represented the technological frontier in the past. The North-South model may continue to be useful, but now a different set of countries composes the two poles of the system.

Import tariffs have effects on $h$ and $\alpha$ too, but in this case the final effects of industrial policy are more ambiguous. Tariffs create a wedge between the borderline good $N^{\mathrm{x}}$ exported and the borderline good $N^{\mathrm{m}}$ imported. The set of goods in the interval

\footnotetext{
${ }^{13}$ The problems brought about by the appreciation of the real exchange rate in Latin America have been a crucial concern for policy makers. See on this Ocampo et al, (2009), Frenkel and Rapetti (2011) and Bresser Pereira (2011).
} 
$\left(N^{X} \ldots N^{m}\right)$ will not be traded (see the upper half of figure 4). Since, firstly, we have assumed that the income elasticity ratio is a function of the number of goods exported and imported by the South; secondly, tariffs do not affect the number of goods exported and hence do not affect the income elasticity of exports (this is not always the case, as will be discussed below); and thirdly, tariffs reduce the number of goods imported and hence the income elasticity of imports, then it can be concluded that tariffs raise the income elasticity ratio. This is represented in the lower half of figure 4 below through a steeper elasticity curve (higher $h$ ), as opposed to the punctuated curve which represents the scenario with no tariffs. Higher rate of growth are obtained in the post-tariff scenario (point B) than in the pre-tariff scenario (point A). But this positive initial effect should be assessed in the light of other effects associated with long periods of protection.

In effect, a limited period of protection may encourage diversification, growth and learning, as suggested by the traditional infant industry argument. But at variance with export subsidies, long periods of protection reduce the rate of learning in the economy (lower $\alpha$ or b), either because competition becomes less intense, the size of the markets smaller or some of the goods previously imported are significant inputs in the production process of other sectors. While export promotion fosters both diversification and learning, import substitution may produce ambiguous effects on learning if tariffs are not a transitory devise in the quest of international competitiveness.

The East Asian countries represent an interesting example of accumulation of technological capabilities which combined a period of import-substituting industrialization with a decisive subsequent drive towards world exports. Although both regions (Latin America and East Asia) are examples of what can be considered state-led growth (see Bértola and Ocampo, 2010), in which industrial policies and various forms of state interventions played a crucial role, the East Asian countries were much more successful than the Latin American ones in fostering structural change and in managing a system of incentives favorable to the learning process (Amsden, 1989; Wade, 1990; Bell, 2006; Peres, 2010).

\section{$\underline{\text { Figure } 4 \text { about here }}$}

\subsection{Trade liberalization}

Trade policies affect both the supply side and the demand side of the relative productivity-elasticity-growth-wages system. We have discussed tariffs in the previous section; we now focus on trade liberalization, whose effects are symmetric. The first major wave of trade liberalization in Latin America happened in the 1970s in the Southern cone, mainly in Argentina, Chile and Uruguay. This experience in trade (and financial) liberalization ended up in the major crises of the eighties, when it was temporarily reverted ${ }^{14}$. Still, the 1990 s witnessed a new regional move in the same direction, which this time seems to have been for good (Stalling and Peres, 2000). Trade liberalization in the 1990s produced two kinds of effects.

One of them is related to the demand side. Trade opening boosted the demand for foreign goods (which had been repressed for many years) and therefore raised

\footnotetext{
14 Rapid trade and financial liberalization combined with abundant supply of foreign private capital produced a sharp appreciation of the real exchange rate that proved to be unsustainable. Similar experiences in the region can be found in the 1990s, particularly in the cases of Brazil, Argentina and Uruguay (see Ffrench-Davis, 2002).
} 
(damped) the income elasticity of the demand for imports (the elasticity ratio) ${ }^{15}$. The other effect is related to the supply side. Domestic firms were rapidly exposed to competition with foreign firms as trade barriers were lifted, in many cases amidst a process of appreciation of the domestic currency, which put further competitive pressure on local production (Katz, 1997) ${ }^{16}$. Some domestic firms had to exit the market, while those that remained (mostly in lower-tech activities) made defensive investments that reduced both the productivity gap and employment levels in the modern sector.

The process begins with a fall in $h$ that shifts the elasticity-diversification curve downwards from point $\mathrm{X}$ to $\mathrm{Y}$ (figure 5B). At the same time firms have to rationalize and downsize their activities in a context of lower growth (figure 5C), out of which the curve of relative productivity moves upwards and becomes steeper (figure 5A). The eventual results are: regressive structural change (lower $N$ ), lower growth and higher heterogeneity (more on this below). Still, as in the case of the Dutch Disease, such an outcome is not inevitable. The economy may come back to the level of diversification $\mathrm{X}$ by a combination of technological policies (shifting the productivity curve further to the right, as shown in the detached line that goes through $\mathrm{X}$ in $4 \mathrm{~A}$ ) and currency devaluation ${ }^{17}$. The specific combination adopted will not of course be neutral in terms of income distribution. There is as well a matter of timing in the choice of policies: devaluation works faster than technological policies. It is reasonable to assume that technological policy would become more important through time, while the need of currency depreciation looses weight in the policy mix.

However, getting back the old level of relative growth requires more than getting back the old level of diversification. To the extent that patterns of demand moved in favor of imported goods, and $h$ is now lower, then to have the same level of relative growth it would be necessary to diversify still further the productive and export structures. Growth is demand-led: higher growth would only occur if international effective demand grows at higher rates, which in our example requires compensating the fall in $h$ by a rise in $N$.

An important aspect of the post-trade liberalization scenario is mounting heterogeneity and inequality (ECLAC, 2010, chapter 3 and Correa, 2011). Two reasons concur to produce such a result. The first is that growth is now slower and ceteris paribus there will be less absorption of workers in the modern sector. A larger share of subsistence workers in total employment boosts inequality. The second reason is that productivity differences across activities in the modern sector are now higher than before liberalization (steeper curve of relative productivity). It is possible that high differences in the levels of productivity encourage differences in wage between workers

\footnotetext{
15 The empirical evidence confirms the strong response of the income elasticity of imports to trade liberalization in Latin America. See Jayme (2003), Holland et al (2004), Pacheco-López and Thirlwall (2006) and Cimoli et al (2010).

${ }^{16}$ Although currency appreciation was a significant factor for regressive structural change in the 1990s and after 2005 in many Latin American countries, we will assume that relative wages remain constant and focus instead on changes in elasticities and productivity.

${ }^{17}$ The specific combination adopted will not of course be neutral in terms of income distribution. There is as well a matter of timing in the choice of policies: devaluation works faster than technological policies. It is reasonable to assume that technological policy would become more important through time, while the need of currency depreciation looses weight in the policy mix.
} 
in sectors at the top and workers in sectors at the bottom of the curve of relative productivity.

\section{Figure 5 about here}

\section{The Dynamic System}

This section discusses in more detail the dynamics of the technology gap and specialization. We move from the comparative statics analysis of the previous sections to full dynamics, which allows for discussing the transition between equilibria. Equation (1) gives the dynamics of the technology gap:

(1) $\dot{G}=u-v G-g y$

The diversification of the Southern economy increases when relative productivity is higher than relative wages, as stated below, where $\lambda$ is the velocity with which the productive structure responds to new opportunities in the domestic and foreign markets:

(19) $\dot{N}=\lambda(\pi-W)$

Using equations (4), (5) and (11), equation (19) can be written as:

$$
\text { (20) } \dot{N}=\lambda[a-k G-(b+j h) N]
$$

The equilibrium solutions are those discussed in section 1. The analysis of stability requires computing the Jacobian of the dynamic system formed by equations (1) and (20):

$$
\text { (A.4) } J=\left|\begin{array}{cc}
-v & -g h \\
-k & -(b+j h)
\end{array}\right|
$$

The trace is $-v-(b+j h)<0$ and hence always negative, while the determinant is $v(b+j h)-k g h$. Stability requires $v(b+j h)>k g h$ (otherwise we have a saddle path). Recalling that $\alpha \equiv k g / v$, it can be seen that the stability condition implies $b+h(j-\alpha)>0$. Also note that for having a positive solution for $N^{*}, W^{*}$ and $y^{*}$, such a condition must be satisfied, as seen in equations (14)-(16).

A policy fostering high-tech goods will raise both $h$ and $\alpha$, leading to higher growth and a more technologically intensive economic structure. If such a policy is pursued for a long period, the system may become instable, as the stability condition will no longer hold. The final result will be a change of positions of North and South, as the South develops a technological advantage respecting the North.

An opposite outcome emerges when the efforts of a country for catching up are too weak and hence there is no room for international spillovers of technology. In such a case the parameter $v$ in equation (1) is negative. In other words, there is no advantage in being a follower, since cumulativeness in the centre overcomes any effort for imitation in the South. Innovation in the North always exceeds diffusion towards the South. The equilibrium solution is then a saddle point and economies diverge in terms 
of technological capabilities, wages and growth, giving rise to a scenario of growing international inequality.

\section{Concluding remarks}

This is a particularly good moment to advance heterodox proposals in the academic and policy agendas. Firstly, the Great Recession reinvigorated Keynesian ideas which came to rescue the global economy from the wreckage brought about by supposedly highly rational agents. Secondly, the international economy has been transformed by the underlying currents of structural change and catching up led by a group of (mainly) Asian developing economies. Understanding the new role they play and the emerging patterns of trade and growth they have produced requires models that place the accumulation of technological capabilities, export growth and structural change at the very centre of the analysis. We have argued that LAS offers a valuable contribution to explain the macrodynamics behind these transformations.

LAS is part of the heterodox tradition in growth theory, with a focus on the specific problems of countries which began to industrialize when others had already accumulated substantial technological capabilities. The emergence of the centreperiphery system placed new questions discussed by LAS. The model presented in this paper, firstly, aims to capture key insights of the LAS school, such as the persistency of technological asymmetries and structural heterogeneity; secondly, it can be used to analyze the impacts of shocks and policies based on how they affect the supply-side and demand-side parameters of the model; thirdly, it links more closely (Post-) Keynesian macroeconomics with the evolutionary microeconomics of learning; and last but not least, it can be used as a toolbox in the analysis of the interactions between structural change, technological catching up and long run growth.

Clearly, there is a long list of topics not addressed in the paper which are important for both heterodox thinking in general and LAS in particular. To mention just two of these topics: problems of institution-building and the political economy of industrial policy; the evolution of income distribution, which throughout the model remained implicit in the response of relative wages to growth. Still, the objective has not been to offer a comprehensive view of LAS. Rather, we aimed at presenting some of its contributions in a way conducive to further extensions and cumulativeness in the heterodox growth tradition. 
Figure 1. A negative shock of external demand

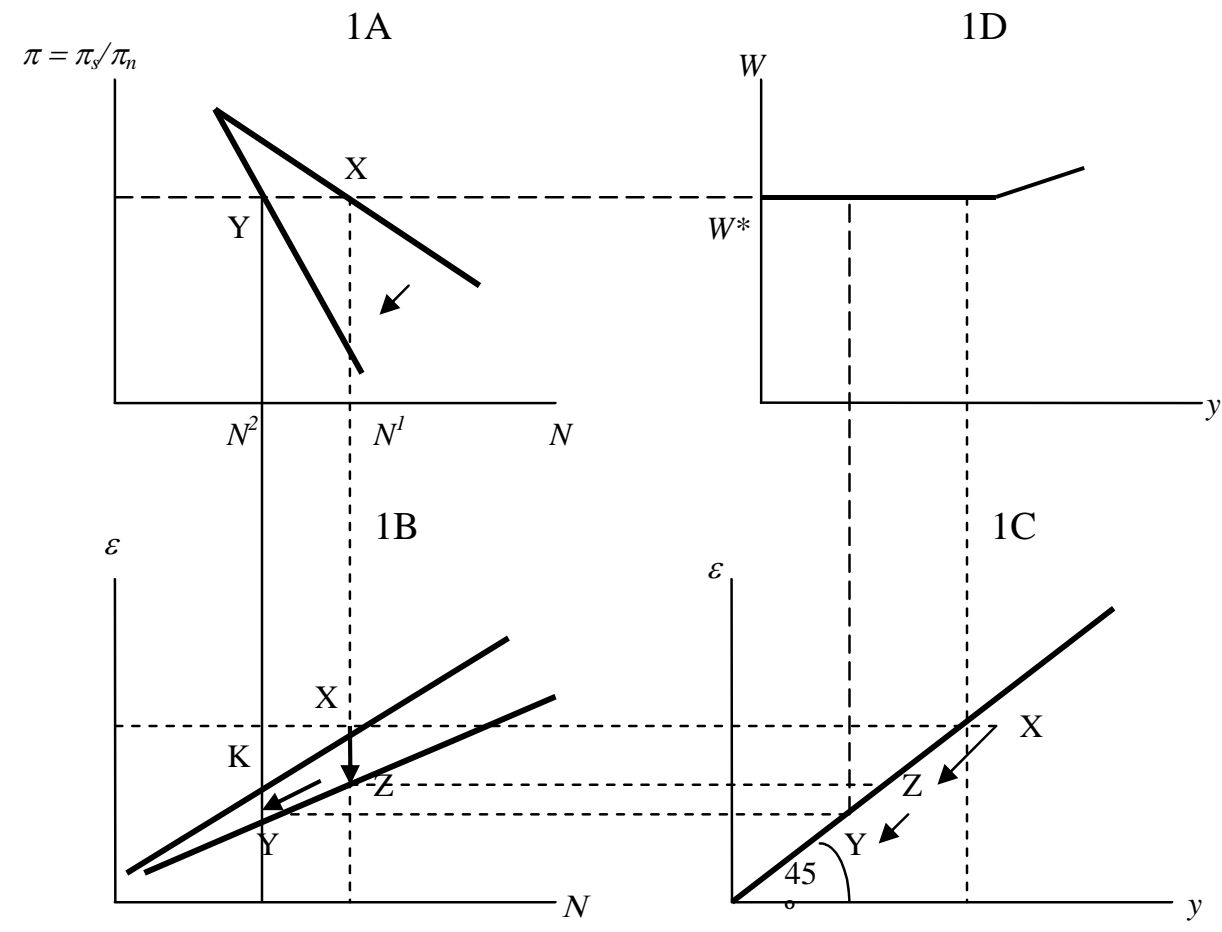


Figura 2. A positive shock of external demand

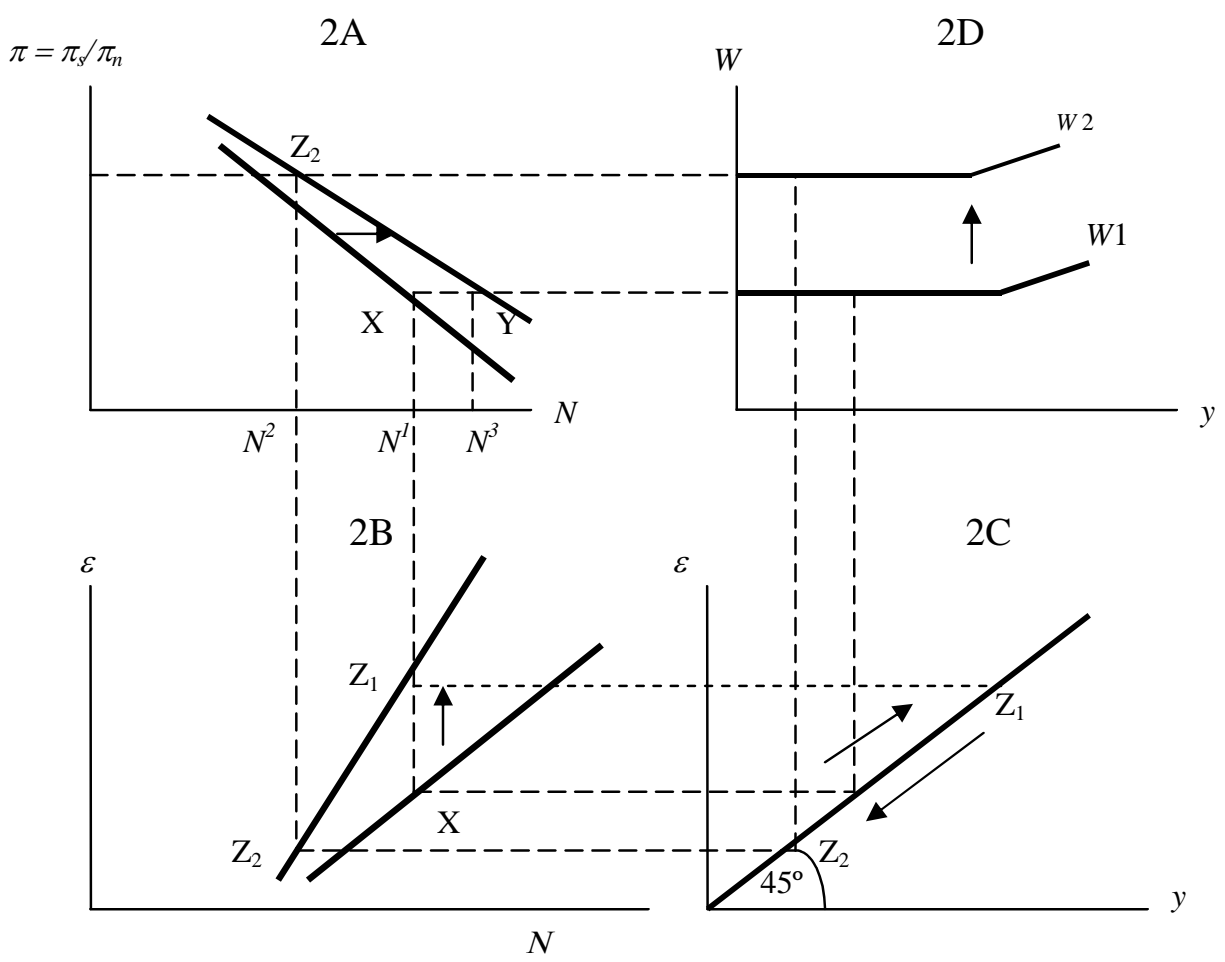


Figura 3. Technological policy

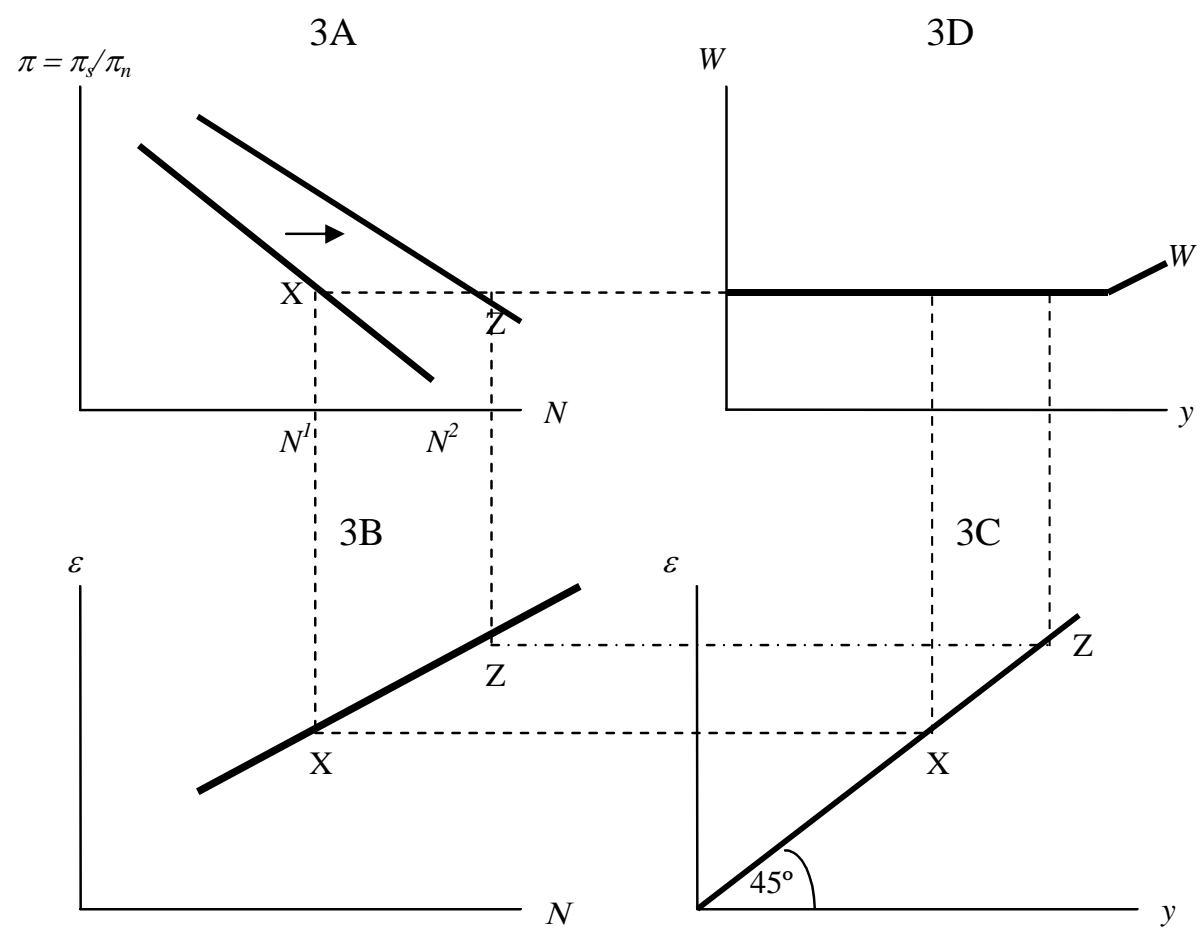


Figura 4. Tariffs, diversification and growth

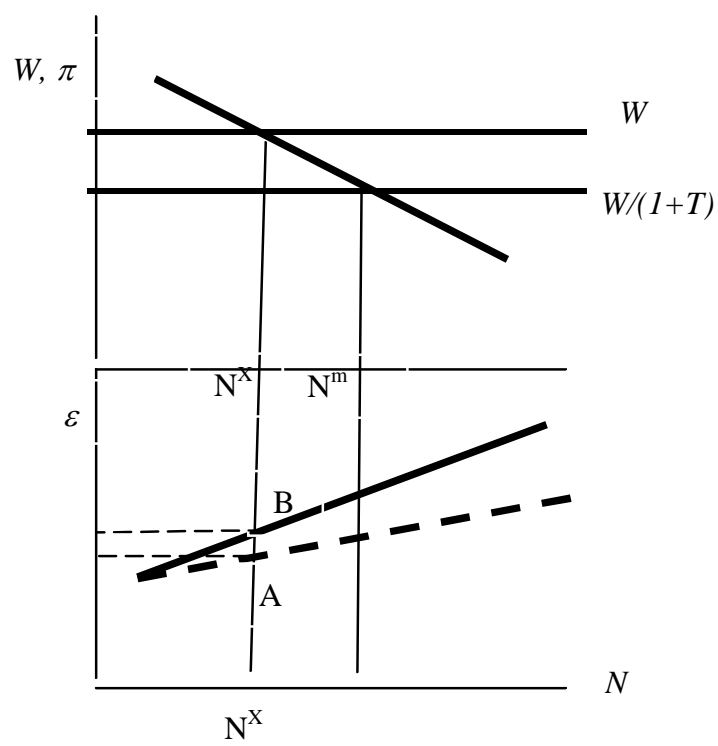


Figure 5. Trade liberalization

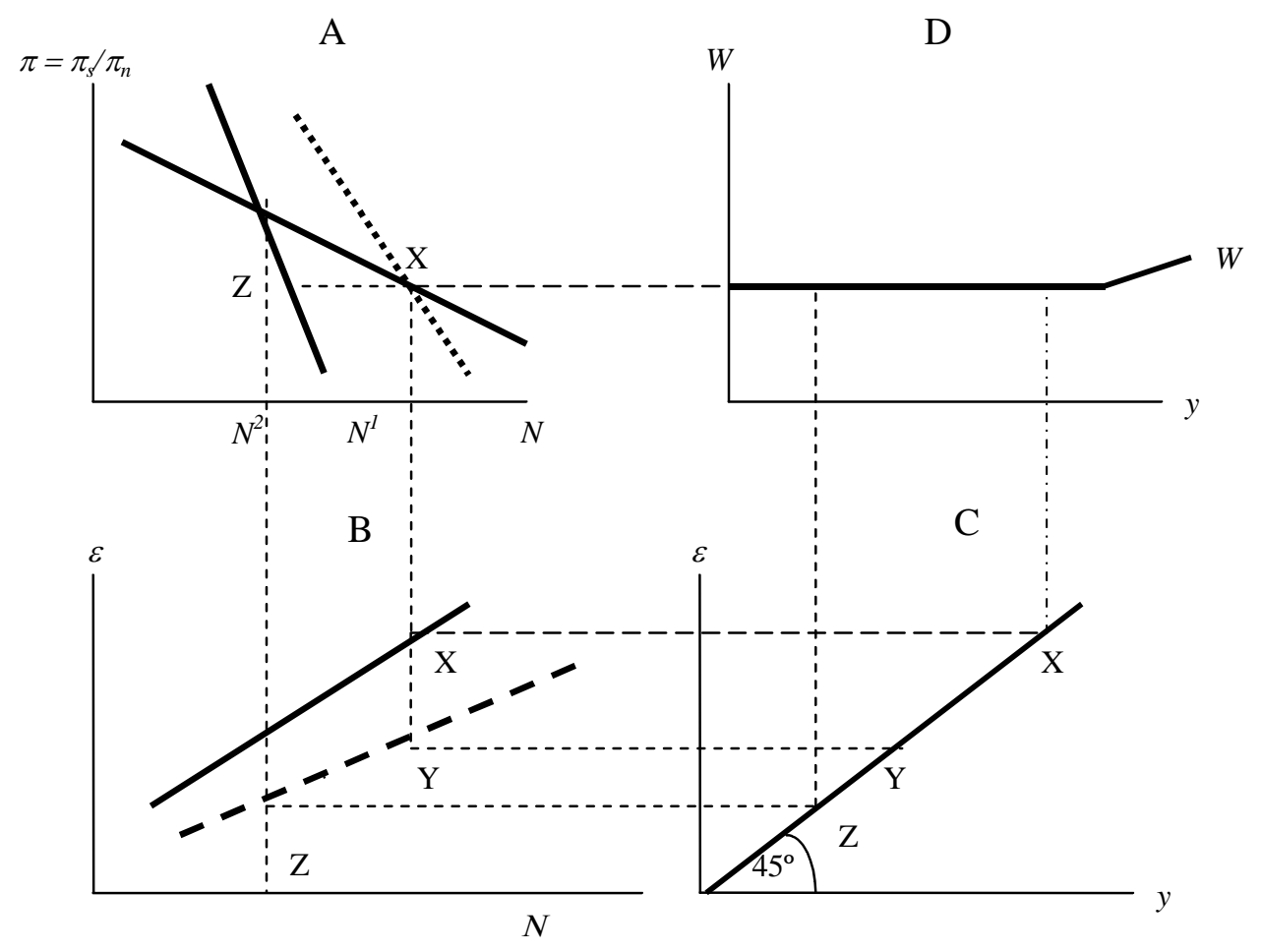




\section{References}

Amsden, A. (1989), Asia's Next Giant: South Korea and Late Industrialization, New York, Oxford University Press.

Araujo, R.A. and G. T. Lima (2007) 'A Structural Economic Dynamics Approach to Balance of Payments Constrained Growth', Cambridge Journal of Economics, 31(5), pp. 755-774.

Bell, M. (2006), “Time and Technological Learning in Industrialising Countries: How Long Does it Take? How Fast is it Moving (If At All)?" International Journal of Technology Management, vol. 36, No. 1-3, pp. 25-39.

Bértola, L. and Ocampo, J.A. (2010), Desarrollo, vaivenes y desigualdad: Una historia económica de América Latina desde la independencia, Madrid: SEGIB.

Bielshowski, R. (2009) "Sixty Years of ECLAC: Structuralism and Neo-Structuralism", CEPAL Review, April, pp. 171-192.

Blecker, R.A. (2011) "Long-run growth in Open economies: Export-Led Cumulative Causation or a Balance-of-Payments Constraint?" in G. Harcourt and P. Kriesler, eds., Handbook of Post-Keynesian Economics. Oxford: Oxford University Press, forthcoming.

Botta, A. (2009) "A Structuralist Noth-South Model on Structural Change, Economic Growth and Catching up", Structural Change and Economic Dynamics 20, pp. 61-73.

Bresser-Pereira, Luiz Carlos (2008) "Dutch Disease and its Neutralization: a Ricardian Approach", Brazilian Journal of Political Economy 28 (1) January, pp. 47-71.

Ciarli, T., Lorentz, A., Savona, M., \& Valente, M. (2010). "The Effect of Consumption and Production Structure on Growth and Distribution. A Micro to Macro Model”, Metroeconomica, 61(1), pp. 180-218

Cimoli, M. (1988), "Technological Gaps and Institutional Asymmetries in a NorthSouth Model with a Continuum of Goods", Metroeconomica, vol. 39, No. 3, pp. 245-74.

Cimoli, M. and Porcile, G. (2011a) "Global growth and International Cooperation: a Structuralist Perspective" Cambridge J. of Economics, 35 (2), pp. 383-400.

Cimoli and Porcile (2011b) "Learning, Technological Capabilities and Structural Dynamics", in Ocampo, J.A. and Ros, J. (2011) The Oxford Handbook of Latin American Economics, Oxford University Press.

Cimoli, M.; Porcile, G. and Rovira, S. (2010) "Structural Change and the BOP Constraint: Why did Latin America Fail to Converge?" Cambridge J. of Economics (2010) 34(2), pp. 389-411.

Correa, N. (2011). "Technological Backwardness and Widespread informality: The Latin American Constraints Towards a More Effective Trade Openness." Doctoral dissertation, Sant'Anna School of Advanced Studies, July 2011.

Dornbusch, R., Fischer, S. and Samuelson, P. (1977) "Comparative Advantage, Trade, and Payments in a Ricardian Model with a Continuum of Goods", American Economic Review 67 (5), pp. 823-839.

Dosi, G. (1988), "Sources, Procedures and Microeconomic Effects of Innovation", Journal of Economic Literature, 26(3), pp. 1120-1171

Dosi, G.; Pavitt, K. and Soete, L (1990) The Economics of Technical Change and International Trade. Brighton: Wheatsheaf. 
Dosi, S. Lechevalier, A. Secchi (2010) "Introduction: Interfirm heterogeneity? Nature, sources and consequences for industrial dynamics Industrial And Corporate Change, 19(6), pp. 1867-1890.

Dutt, A.(2002) “Thirlwall's Law and Uneven Development”, Journal of Post-Keynesian Economics, 23(3), pp. 367-90.

ECLAC (1955) Estudio Económico de América Latina, 1954. ECLAC: Santiago de Chile.

ECLAC (2007) "Progreso Técnico y Cambio Estructural en América Latina", Santiago de Chile: Division of Porductivity and Management, ECLAC, October.

ECLAC (2010) Time for equality: Opening Trails, Closing Gaps, Chile: United Nations.

Freeman, C. (1995) "The National System of Innovation in Historical Perspective", Cambridge Journal of Economics, v. 19 (1), pp. 5-24.

Ffrench-Davis, R (2002) Chile between Neoliberalism and Equitable Growth, University of Michigan Press.

Frenkel, R. and Rapetti, M. (2011) "A Concise History of Exchange Rate Regimes in Latin America", in Ocampo, J.A. and Ros, J. (2011) The Oxford Handbook of Latin American Economics, Oxford University Press.

Gouvea, R.R. and G.T. Lima (2010) "Structural Change, Balance of Payments Constraint and Economic Growth : Evidence from the Multi-Sectoral Thirlwall's Law", Journal of Post Keynesian Economics, 33 (1), October, pp. 169-204.

Infante, R, y Sunkel, O. (2009) "Chile: Hacia un desarrollo inclusivo", Revista de la CEPAL, 98, April, pp. 135-154.

Holland, M., F.V. Vieira and O. Canuto (2004) 'Economic Growth and the Balance of Payments Constraint in Latin America', Investigación Económica, LXIII (249), pp. 45-74.

Jayme, F.G. (2003) 'Balance of Payments Constrained Economic Growth in Brazil', Brazilian Journal of Political Economy, 23 (1), pp. 62-84.

Katz, J. (1997), "Structural Reforms, the Sources and Nature of Technical Change and the Functioning of the National Systems of Innovation: The Case of Latin America", paper presented at the STEPI International Symposium on Innovation and Competitiveness in NIEs" Seoul, Korea, May.

León-Ledesma, M.A. (2002) “Accumulation, Innovation and Catching-up: an Extended Cumulative Growth Model”, Cambridge Journal of Economics, 26, pp. 201 - 216.

Lewis, A. (1954) "Economic Development with Unlimited Supplies of Labor", Manchester School of Economics and Social Studies (32), pp. 1-32.

McCombie, J.S.L and Thirlwall (1994) Economic Growth and the Balance of Payments Constraint. New York: St. Martin Press.

McCombie, J.S.L and Thirlwall (1997) "The Dynamic Harrod Trade Multiplier and the Demand-Oriented Approach to Economic Growth: An Evaluation", International Review of Applied Economics, 11 (1), pp. 5-26.

Metcalfe, J. S. (2001), "Institutions and Progress," Industrial and Corporate Change, Oxford University Press, 10(3), pages 561-86, September.

Moreno-Brid, J. (2003) "Capital Flows, Interest Payments and the Balance of Payments Constrained Growth Model: A Theoretical and Empirical Analysis", Metroeconomica, 54 (3), pp. 346-365. 
Narula, R. (2004)“Understanding Absorptive Capacities in an Innovation Systems Context: Consequences for Economic and Employment Growth", DRUID Working Paper n. 04-02, December.

Ocampo, J.A., Rada, C and Taylor, L. (2009) Growth and Policy in Developing Countries: A Structuralist Approach. Oxford University Press.

Pacheco-Lopez, P. and Thirlwall, A.P. (2006) "Trade Liberalization, the Income Elasticity of Demand for Imports and Economic Growth in Latin America", Journal of Post-Keynesian Economics 29 (1), pp. 41-61.

Peres,W. (2010), "The (slow) return of industrial policies in Latin America and the Caribbean", M. Cimoli, G. Dosi and J. E. Stiglitz (eds) The Political Economy of Capabilities Accumulation: the Past and Future of Policies for Industrial Development, Oxford University Press.

Pérez, E. (2011) "Growth and convergence/divergence in productivity under balance-ofpayments constraint”, Investigación Económica, LXX (275), pp. 15-38.

Pinto, A. (1976), "Naturaleza e implicaciones de la heterogeneidad estructural de la América Latina", en El Trimestre Económico, vol. 37 (1), n. 145.

Porcile, G. and Lima, G. (2010) "Real exchange rate and elasticity of labour supply in a balance-of-payments-constrained macrodynamics ",Cambridge Journal of Economics, 2010, 34 (6), pp. 1019-1039.

Prebisch, R. (1949) El Desarrollo Económico de América Latina y su Principales Problemas (New York: United Nations, 1950)

Rada, C. (2007) "Stagnation or transformation of a dual economy through endogenous productivity growth", Cambridge Journal of Economics 31(5), pp. 711-740.

Reinert, E.S. (1995) "Competitiveness and its predecessors - a 500 year cross-national perspective" in Structural Change and Economic Dynamics, Vol. 6, pp. 23-42.

Rodríguez, O. (1977) "Sobre la Concepción del Sistema Centro-Periferia”, Revista de la CEPAL, First Semester.

Rodríguez, O. (2007) El Estructuralismo Latinoamericano. México: Siglo XXI.

Ros, J. (2002) Economic Growth and Development Theory, Michigan University Press.

Setterfield, M. (2009) "Neoclassical Growth Theory and Heterodox Growth Theory: Opportunities For and Obstacles To Greater Engagement", Trinity College Department of Economics, Working Paper 09-1, December.

Stalling, B. and Peres, W. (2000) Growth, Employment and Equity: The Impact of Economic Reforms in Latin Ameerica and the Caribbean, Washington, DC: Brookings Institution Press.

Thirlwall, A.P. (1979) "The Balance of Payments Constraint as an Explanation of International Growth Rate Differences", Banca Nazionale di Lavoro, March, 128, pp. 45-53.

Thirwall, A. (2011) "Balance of Payments Constrained Growth Models: History and Overview". University of Kent, School of Economics Discussion Paper 1111, May.

Vera, L.A. (2006) "The Balance-of-Payments Constrained Growth Model: A NorthSouth Approach", Journal of Post-Keynesian Economics, 29 (1), pp. 67-92. 
Verspagen, B (1993) Uneven Growth Between Interdependent Economies: An Evolutionary View of Technology Gaps, Trade and Growth. Avebury, Ashgate Publisher.

Wade, R. (1990), Governing the Market: Economic Theory and the Role of Government in East Asian Industrialisation, Princeton, Princeton University Press. 